\section{Waneek Horn-Miller: from survivor to indigenous rights champion}

\author{
Christopher Napier
}

\section{THE DAY HER LIFE CHANGED FOREVER} It was 26 September 1990 and after months of a tense stand-off over disputed land, the Oka Crisis in Quebec was at its peak. Mohawk protesters had clashed with Quebec provincial police over the decision to build condominiums and expand a golf course into a forest and burial land that the Mohawk considered sacred. In the middle of it all was 14-year-old Waneek Horn-Miller. A promising young athlete in swimming and track and field, HornMiller had been holed up with her family for weeks behind the blockade while her mother was a negotiator for the Mohawk resistance. During the confusion surrounding the end of the stand-off that day, Horn-Miller was stabbed in the chest with a soldier's bayonet (figure 1). She had been carrying her 4 year-old sister, Kaniehtiio, to safety.

It could have ended there. Not just because the bayonet could have ended Horn-Miller's life-it passed just inches from her heart-but because that moment could have pulled her back in to the never-ending cycle of intergenerational trauma that indigenous people in Canada so often cannot escape. Indigenous people, through generations of suffering, are caught in a cycle and many see no way to get out.

Instead of pulling her deeper into this cycle of marginalisation, that moment in 1990 catalysed Horn-Miller to do something bigger. After locking herself in her room for 6 days and thinking of abandoning her dreams of someday competing at the Olympics, her mother came to her and said, 'If you quit now, you will hand your dream over to that soldier and you will be his victim for the rest of your life. You have to show them that we cannot be beaten. And your vehicle is sports.' That thought of being someone's victim for the rest of her life was not something Horn-Miller could accept. She would be a survivor. She needed to jump off this cycle. She credits the strong influence of

Department of Physical Therapy, University of British Columbia, Vancouver, BC, Canada

Correspondence to Dr Christopher Napier, Department of Physical Therapy, University of British Columbia, Vancouver, BC V6T 1Z3, Canada; chris.napier@ubc.ca her mother (a single mother of four daughters and one of Canada's first indigenous rights activists) as well as the constant gaze from her youngest sibling as factors that kept her focused and motivated to overcome the familiar cycle.

\section{FROM SURVIVOR TO OLYMPIAN}

Ten years later, Waneek Horn-Miller, as co-captain of Canada's first Olympic women's water polo team, led her team into the 2000 Olympic Summer Games in Sydney, Australia. Though that experience ended in a disappointing fifth place finish, on her return to Canada Horn-Miller met with the Mohawk nation's only other Olympic athlete, Alwyn Morris (1984 Olympic gold medalist in sprint kayak). Morris looked her straight in the eye and said, 'You are a great athlete, but do you want to be a great person? The work you do now is what is going to make you that great person. Helping others, raising issues, and using your platform as an Olympian.' Horn-Miller realised that being an Olympian opened doors for her. She garnered respect when she walked into any room from all people, whether they were indigenous or not, because she had earned their admiration on her own merit. She saw that her success at being an athlete could contribute to the greater good and she knew what she wanted to do and how she wanted to make things better.

True to the nature of indigenous language and communication, Horn-Miller tries to
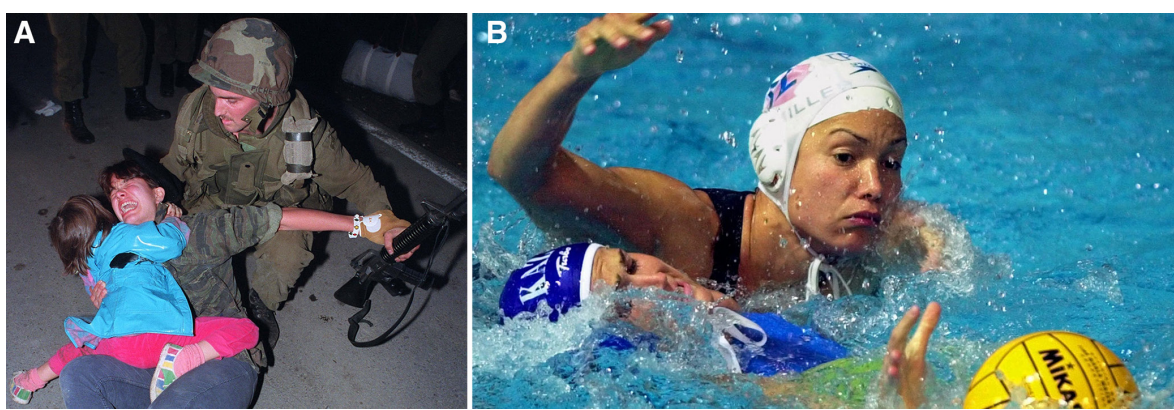

Figure 1 (A) On 26 September 1990, on the final day of the Oka standoff, Waneek Horn-Miller was trying to leave while carrying her 4-year-old sister, Kaniehtiio, when she was stabbed close to the heart by a soldier carrying a bayonet (Photo: Ryan Remiorz/The Canadian Press). (B) HornMiller competes for Canada at the 2000 Olympic Summer Games in Sydney, Australia (Photo: Jeff De Booy/Canadian Press). TION Ambassador to Canada's Assembly of First Nations, where she helped develop a National Indigenous Sport, Fitness and Wellness Strategy. Beside the fact that the current cultural norms in sport make it difficult for Indigenous people to participate and thrive within sport, she believes that indigenous people have something greater to offer sport. She points to recent work in New Zealand to indigenise the Olympic movement. Horn-Miller hopes to one day create a sustainable national indigenous sports system, allowing more people to be physically active and participate as lifelong athletes.

\section{ADVANCING INDIGENOUS AND HUMAN RIGHTS FOR ALL}

Today, Horn-Miller is a graduate student in the Indigenous Studies programme at the University of British Columbia's School of Kinesiology and a motivational speaker promoting the importance of sport and physical activity to Indigenous communities across Canada. She is interested in the cultural, historical, and socioeconomic factors that affect motivation in indigenous people and to understand what allows some people to escape the cycle of trauma while others remain trapped, so that she and others can intervene to improve the health and social outcomes for indigenous people. Horn-Miller is quick to point out that her work is not only about indigenous rights. These are human rights that she is fighting for. Her mission is to convey explain concepts in a way that people can visualise. Once you can see it, she says, you can find a way through it. At the 2010 Winter Olympics in Vancouver, HornMiller noticed that, despite the celebration of indigenous art and culture, there were few indigenous Olympians. This inspired her to become the IndigenAC- 


\section{Service spotlight}

this message not only to indigenous audiences, but to the broader community. As a nation-as humans-indigenous issues should matter to everyone because at their core they are human issues. And as a nation and a people we are all lifted up when we empower those who are most vulnerable. 'As a country,' she says, 'we have an opportunity to achieve something that has never existed on this planet.'

Twitter Christopher Napier @runnerphysio

Funding The authors have not declared a specific grant for this research from any funding agency in the public, commercial or not-for-profit sectors.

Competing interests None declared.

Patient consent for publication Not required.

Provenance and peer review Not commissioned; internally peer reviewed.

Data availability statement No data are available.

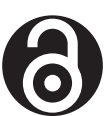

\section{OPEN ACCESS}

Open access This is an open access article distributed in accordance with the Creative Commons Attribution Non Commercial (CC BY-NC 4.0) license, which permits others to distribute, remix, adapt, build upon this work non-commercially, and license their derivative works on different terms, provided the original work is properly cited, appropriate credit is given, any changes made indicated, and the use is non-commercial. See: http:// creativecommons.org/licenses/by-nc/4.0/.

(C) Author(s) (or their employer(s)) 2021. Re-use permitted under CC BY-NC. No commercial re-use. See rights and permissions. Published by BMJ.

\section{(D) Check for updates}

To cite Napier C. Br J Sports Med 2021;55:701-702.

Accepted 24 March 2021

Published Online First 22 April 2021

Br J Sports Med 2021;55:701-702.

doi:10.1136/bjsports-2021-104236

\section{ORCID iD}

Christopher Napier http://orcid.org/0000-0002-14543546 